\title{
IMPACT OF TRAINING AND COMPETENCE ON PERFORMANCE MODERATED BY THE LECTURER CAREER DEVELOPMENT PROGRAM IN PALEMBANG, INDONESIA
}

\author{
Garaika \\ Sekolah Tinggi Ilmu Ekonomi Trisna Negara, Sumatera Selatan \\ Email :garaika.hamzah@gmail.com
}

\begin{abstract}
The existence of this study is to find out whether job training, competence and career development can affect performance, and in this study career development as a moderating variable for the training and competency variables of lecturers in Palembang, Indonesia. The population in this study were college lecturers in Palembang, Indonesia. The sample in this study was 100 respondents who were random samples from college lecturers in Palembang, Indonesia. To see the magnitude of the coefficient of influence between research variables, a survey method with a questionnaire was used. Training, competence, and career development as independent variables. While performance is the dependent variable. The results of this study indicate the significant positive effect of training on career development, the significant positive effect of competence on career development, the insignificant positive effect of training on performance, the significant positive effect of competence on performance and the significant positive effect of career development on performance. Higher education institutions in Palembang, Indonesia are expected to provide clarity on the career development of lecturers through (mutation, selection, placement, education, and training), then consistently given training through (seminars) by bringing in experienced instructors, providing material and quality methods, as well as enhancing the competence of lecturers to increase their knowledge, understanding, abilities, skills, attitudes and interests in accordance with their fields of science.
\end{abstract}

Keywords: Training, Competence, Career Development, Performance

\section{Introduction}

The success of an organization to achieve its vision, mission and objectives must be supported by several factors both internal and external. Internal factors should get more attention than external factors. Therefore, human resources cannot be underestimated, which is only used as a tool in the organization, but must be used as the most important asset in the organization. As the most important asset, human resources need to be well selected, maintained and developed.

The demand to realize good organizational governance in every public organization must be able to work quickly, responsively, transparently, and accountably. And this can only be fulfilled by human resources who have professionalism and high integrity. Therefore, human resources need to be selected, maintained and well developed.

Lecturer performance is an important factor in educational organizations in this case are universities, both private and public. To make professional and integrity lecturers' performance 
a challenge for universities, especially those in Palembang, Indonesia Province. The success of a tertiary institution depends on quality human resources. Lecturers are required to behave in accordance with Tridharma Higher Education including in terms of education or teaching of students, research activities, and community service aimed at providing services and helping the community in accordance with the field of science.

In addition to running the Higher Education Tri Dharma, lecturers also play a role in the success of the educational process and also play a role in the implementation of governance that supports the development and progress of each university. Administrative lecturer is a person who has academic expertise who is appointed by the college where they devote themselves.

Anticipating changes and demands of the times, organizations need to make adjustments, need to prepare human resources (HR) to increase the capacity and performance of $\mathrm{HR}$ to continue learning through debriefing, attitudes and skills. Education and training according to Dessler (2011) learning activities that teach about skills that can be used to support the work of employees. Notoatmodjo (2009) training is an effort related to improving the ability or skills of employees who occupy a particular job or task. According to Government Regulation of the Republic of Indonesia Number 101 of 2000 concerning Education and Training of Civil Servants' Position is the process of organizing teaching and learning in order to improve the ability of Civil Servants. Education and training include two functions at once, namely the education function and the training function which are an inseparable unit. Rivai (2010) training is an activity directing employee behavior to achieve organizational goals. Training is very closely related to the ability and skills of an employee at work.

In addition to providing attitudes or skills to lecturers, universities must also work to improve the quality of lecturer competencies to be able to know the level of knowledge, expertise, and attitude of lecturers who are believed to be able to influence lecturer performance. Mathis (2010) factors that influence employee performance include individual abilities, effort devoted and organizational support. And one of the factors that can affect employee performance is the competency of the individual.

Mangkunegara (2013) human resource management as a management and utilization of existing resources in individuals. Performance is influenced by several factors, one of which is organizational support. One form of support provided by organizations to employees is career development for employees. Oduma (2014) a leader who expects the achievement of maximum performance must pay attention to the factors that influence the performance of the employees themselves, one of which is career development. One formal approach taken to ensure that employees have the necessary qualifications, abilities and work experience is to provide career development (Kasegar, 2013).

Previous studies that explored the role of training, competence, and career development in improving performance have done so many, including studies by; Asrizallis (2015) where the results of this study concluded that training contributed significantly to performance, Wirotomo (2015) this study concluded that partially competence, career development, and job training has a positive effect on developing employee performance, Research conducted by Satriadi (2018) states that job training can affect performance positively, a study by Hendra (2018) based on the results of his study stated competence has a positive influence on performance, Rusvitawati (2019) competence has a significant positive effect on performance, Ningsi (2015) states that training influences performance but is not significant, Mubarok (2018) results his research states that training and competence can be considered variables to improve performance, Watulo (2018) the results of this study say that training does 
Vol-4, Issue-3, 2020 (IJEBAR)

E-ISSN: 2614-1280 P-ISSN 2622-4771

http://jurnal.stie-aas.ac.id/index.php/IJEBAR

not affect performance partially, but simultaneously which include career development and competence variables in improve performance. And some of the following research results which state that the variables of training, competence and career development can improve performance, including: Truit (2011), Karim (2019), Imran (2015), Mahmood (2018), AlSharafi (2018), and Boadu (2014).

\section{Theoretical Framework And Hypotheses}

\subsection{Training}

Training according to Mathis (2002) is an individual process in achieving its ability to achieve organizational goals. And the process is closely related to the vision, mission, and goals of the organization. As for training, it can be seen as a supporting variable. In a narrow sense, training is an effort to prepare employees for specific knowledge and skills that can be used in their work. Whereas Dessler (2011) training is a process of teaching the skills needed by employees to do their jobs. Simanungkalit (2011) training and education for employees is a requirement to be able to improve skills, expertise, and knowledge in supporting work.

Rivai (2010) training is another side of education that requires a learning process to improve skills in a short time, of course, with methods that prioritize practice rather than theory. Suparyadi (2015) the objectives of the training include: increasing productivity, increasing effectiveness and efficiency, and increasing competitiveness. While the benefits of training are: increase independence, increase motivation, foster a sense of belonging, reduce employee discharge, and increase company profits. And the following researchers: Truit (2011), Karim (2019), Imran (2015), Mahmood (2018), Al-Sharafi (2018), and Boadu (2014), Asrizallis (2015), Wirotomo (2015), and Satriadi (2018) in general the results of his study stated that training together with other variables including competence and career development can improve performance.

\subsection{Competence}

Competence according to Sedarmayanti (2014) is a characteristic that underlies individuals to achieve superior performance. Competency improvement requires knowledge, skills and abilities to support the work done. Wibowo (2016) competence is the ability to carry out or do a job or task that is based on the skills and work knowledge that dituntu by the job. Edison (2016) Competency indicators are knowledge, expertise and attitude.

Spencer in Moeheriono (2014) competence as character or character of someone related to employee performance in carrying out their work, or character of someone employee who has a cause and effect relationship which can then be used as reference material. Dessler (2010) the importance of employee competencies is as: to know how to think cause and effect that is critical, understand the principles of good measurement, ensure the cause and effect relationship, and communicate the results of strategic work. Gordon in Sutrisno (2011) some aspects contained in the concept of competence are: knowledge, understanding, abilities / skills, values, attitudes, and interests. Human resources can remain gradual because they have managerial competence, namely the ability to formulate a company's vision and strategy and the ability to acquire and make an employee participate in achieving the vision, mission, and goals and strategies of the organization. The following researchers, Truit (2011), Karim (2019), Imran (2015), Mahmood (2018), Al-Sharafi (2018), and Boadu (2014), Asrizallis (2015), Wirotomo (2015), Hendra (2015), Hendra (2015), 2018), Rusvitawati (2019), Mubarok (2018), and Satriadi (2018) where in general their study results stated that competency along with other variables including training and career development could improve performance. 


\subsection{Career Development}

Simamora (2013) career development is a formal way taken by the company to ensure that employees with sufficient qualifications and experience can occupy strategic positions in the company, thus career development can benefit both employees and the company. Meanwhile, according to Ardana et al (2012) career development is a personal improvement by someone to achieve a career plan and improvement by the personnel department to achieve a work plan in accordance with the organizational career path.

A leader who hopes to achieve maximum performance in an organization must pay attention to factors that affect the performance of its employees, one of which is career development (Caroline, 2014). This opinion supports the opinion of Crowley et al (2012) who say career development has an impact on employee career direction.

Then Rivai (2011) said career development is a process of increasing individual work skills achieved in order to achieve the desired career. Khan et al (2015) states that career development plays an important role in the development of human resources in companies. Pareek (2012) argues that employee career development must be seen as an investment not a cost and that poor performance and low commitment are a cost in the organization. Meanwhile Harlie (2010) states that career development has long-term career benefits that help employees to be more responsible in the future. There are several researchers including Truit (2011), Karim (2019), Imran (2015), Mahmood (2018), Al-Sharafi (2018), and Boadu (2014), Asrizallis (2015), Wirotomo (2015), Hendra (2018) ), Rusvitawati (2019), Mubarok (2018), and Satriadi (2018) where in general their study results stated that career development can improve performance.

\subsection{Performance}

Based on the opinion of Roring (2017) performance is the result or performance achieved by employees in carrying out their work. Performance is another form of skill, experience, and sincerity as well as time dedicated to the company. Mahsun (2006) has the opinion that performance is a manifestation of the achievement of an activity in realizing the company's vision, mission, goals and objectives. Fahmi (2011) performance is the result obtained by an organization that is profit oriented and non profit oriented which is produced during a certain period of time.

Rivai (2013) argues that performance is the result of work or individual success of the task that must be done, which is determined and agreed upon together. Wibowo (2016) performance is about doing work and the results achieved from the work. Performance is what is done and how to do it. Meanwhile Mangkunegara (2010) performance comes from the word job performance or actual performance. Performance is the result of individual work in the form of quality and quantity as a responsibility given to that individual. Some studies on performance include: Truit (2011), Asrizallis (2015), Wirotomo (2015), Ningsi (2015), Imran (2015), Candra (2016), Satriadi (2018), Watulo (2018), Mubarok (2018)), Mahmood (2018), and Al Sharafi (2018), Al Karim (2019), Hendra (2018), Rusvitawati (2019), Tafqihan (2014), Wahyuni (2019), Boadu (2014), Siswadhi (2018), and Marjanuardi (2019), where their study generally concluded that church variables could be improved through variables including training, competence and career development. 


\subsection{Research Framework}

Based on the proposed research hypothesis, as well as past studies, the research framework is as follows:

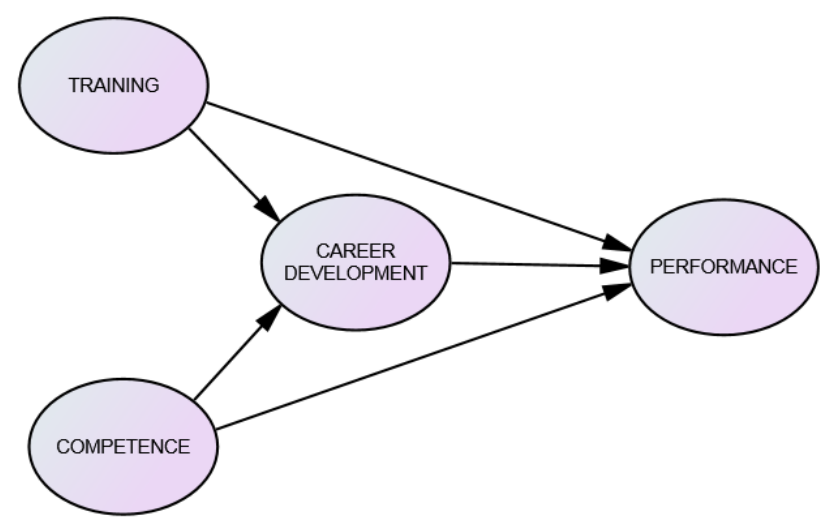

Figure 1. Research

Diagram

Based on a review of the conceptual framework of the study the hypotheses of this study are as follows:

H1 : Training influences career development

$\mathrm{H} 2$ : Competence influences career development

H3 : Training influences lecturer performance

H4 : Competence influences lecturer performance

H5 : Career development influences the performance of lecturers

\section{Research Method}

The population in this study is permanent and non-permanent lecturers of Higher Education in Palembang, Indonesia. The sample taken was 100 respondents. In this study the questionnaire instrument was used as an analysis tool. Data from the questionnaire results were then analyzed to obtain valid and reliable data regarding the training variables, competence and career development on the performance of university lecturers in Palembang, Indonesia. Analysis of research data using descriptive and inferential statistical methods. Analysis models using Structural Equation Model (SEM) with statistical analysis tools using the Smart_PLS version 2.0 computer program are used to answer hypotheses.

\section{Result And Discussion}

To test the coefficient of indicators on each study variable, a goodness of fit index (GOF) analysis was used. Then do the validity test to test the indicator whether it has a valid coefficient or not in accordance with the requirements. In Table 1 is the result of validity testing, and obtained all items of research indicator questions have a value greater than 0.5 so that it can be concluded that all questions of the research indicators are valid. In Table 2 shows the value of C.R is greater than 0.7 explains that all variables can be forwarded for research. In other words all indicators through questionnaire questions can be used as a tool to measure research variables. 
International Journal of Economics, Business and Accounting Research (IJEBAR)

Peer Reviewed - International Journal

Vol-4, Issue-3, 2020 (IJEBAR)

E-ISSN: 2614-1280 P-ISSN 2622-4771

http://jurnal.stie-aas.ac.id/index.php/IJEBAR

Table 1. Testing Validity of Research

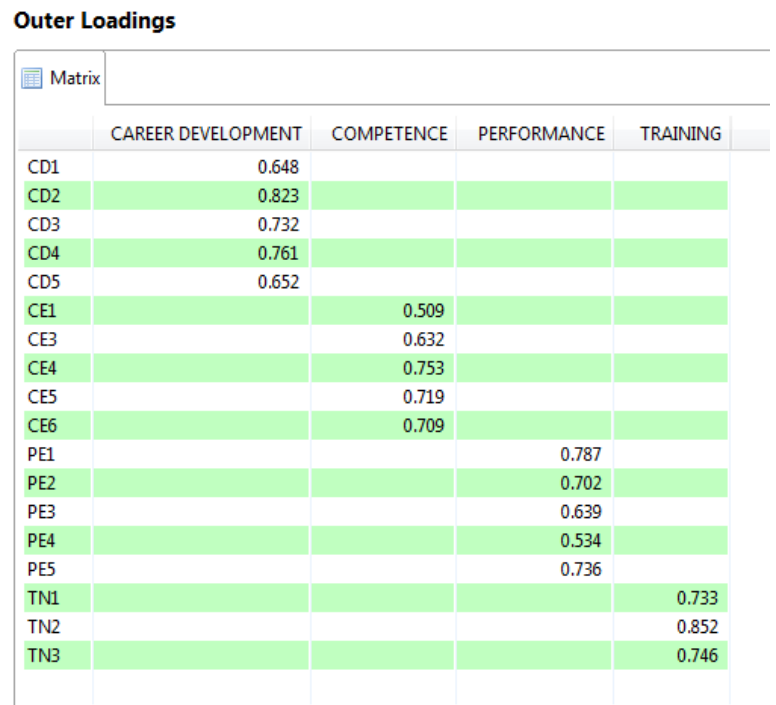

Table 2. Research Reliability Testing

Composite Reliability

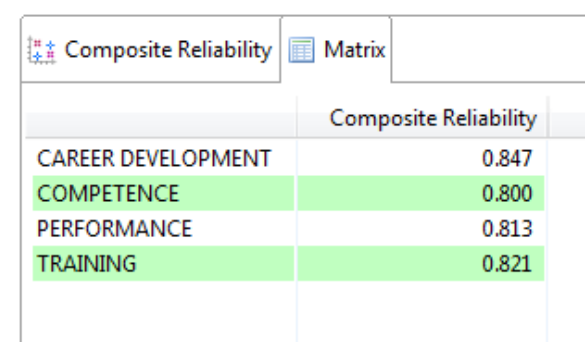

To test the hypothesis proposed in this study the Smart_PLS version 2.0 analysis tool was used. Based on the test results that can be seen in Figure 1, and Table 3 the research model has coefficients that have met the criteria for goodness of fit index (GOF). All GOF criteria are in accordance with the required cut-off. 
International Journal of Economics, Business and Accounting Research (IJEBAR)

Peer Reviewed - International Journal

Vol-4, Issue-3, 2020 (IJEBAR)

E-ISSN: 2614-1280 P-ISSN 2622-4771

http://jurnal.stie-aas.ac.id/index.php/IJEBAR

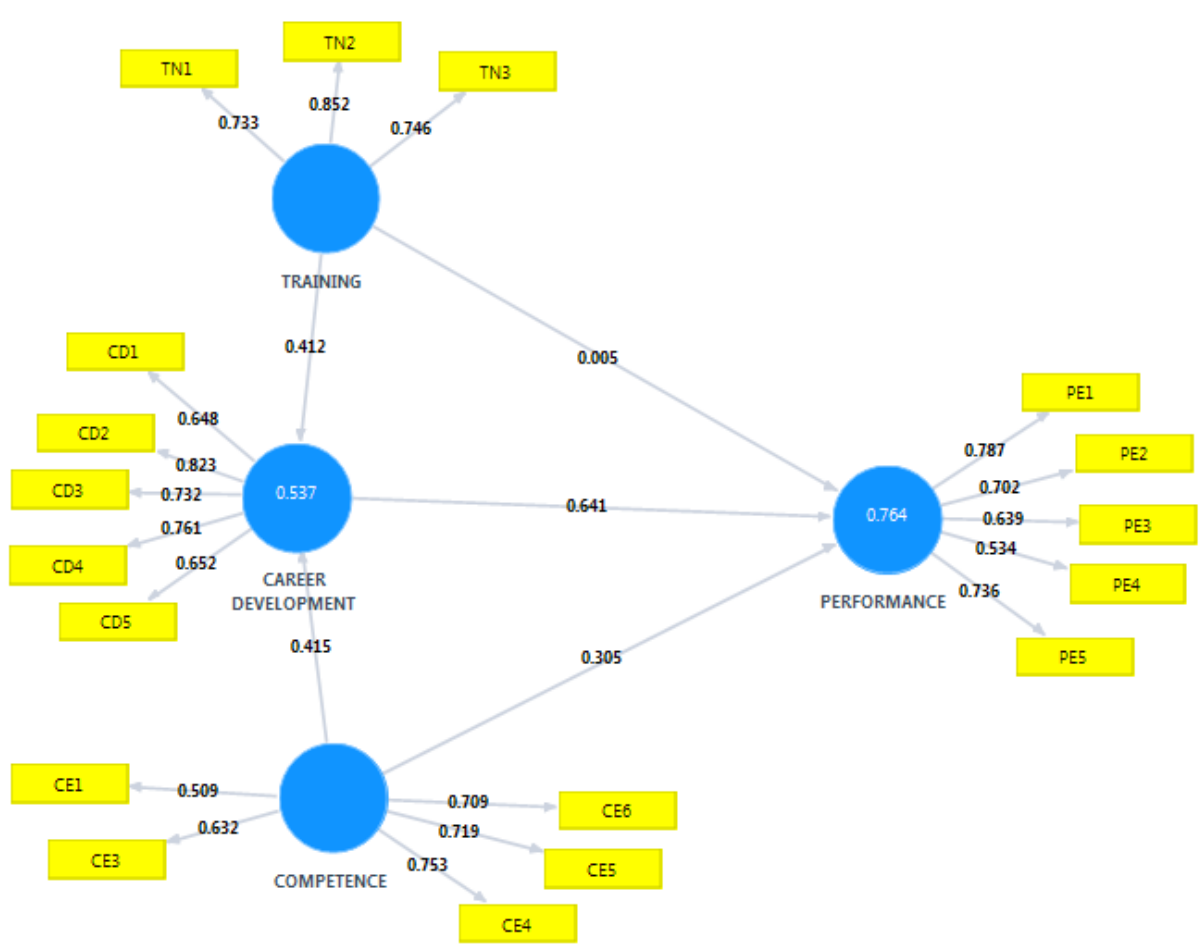

Figure 1. Regression Analysis of Research Models

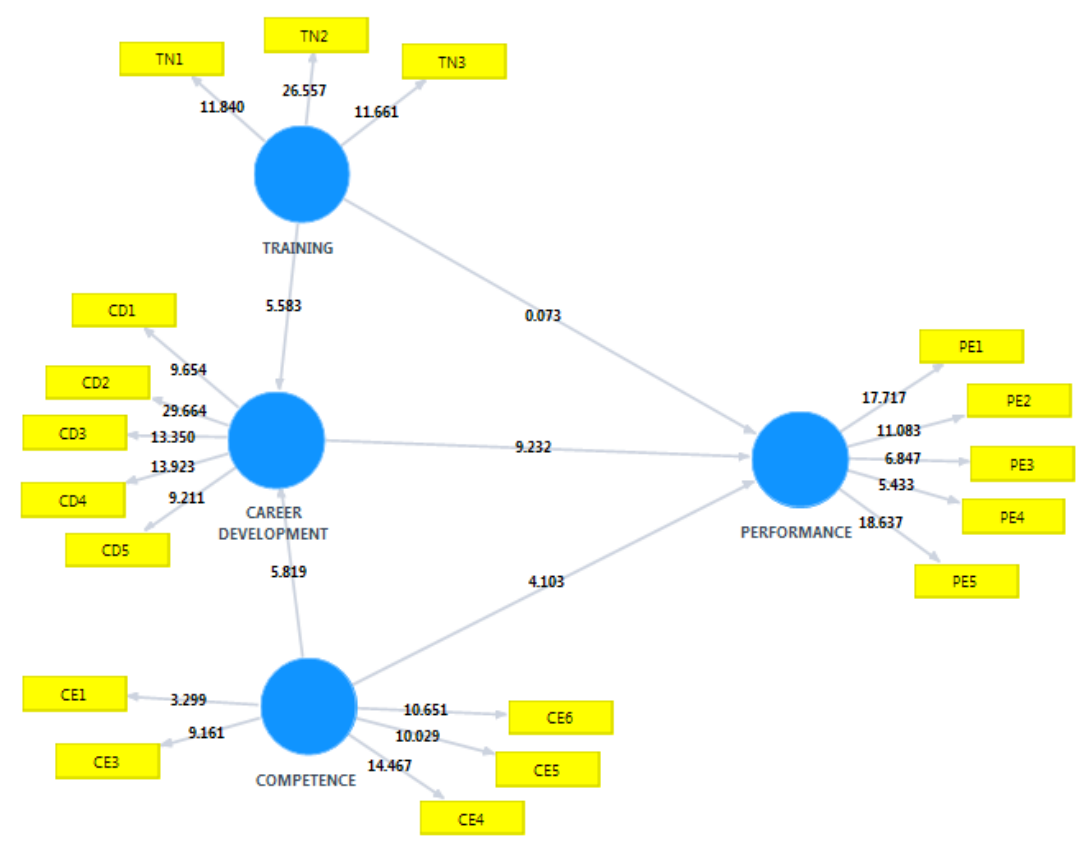

Figure 2. Analysis of the $t$ Test Analysis of the Research Model 
International Journal of Economics, Business and Accounting Research (IJEBAR)

Peer Reviewed - International Journal

Vol-4, Issue-3, 2020 (IJEBAR)

E-ISSN: 2614-1280 P-ISSN 2622-4771

http://jurnal.stie-aas.ac.id/index.php/IJEBAR

Table 3. Structural Parameters Estimating Direct Effects: Path Analysis Model

Path Coefficients

\begin{tabular}{|c|c|c|c|c|c|c|c|c|}
\hline \multirow[t]{2}{*}{ Mean, STDEV, T-Values, P-Values } & \multicolumn{2}{|c|}{ Confidence Intervals } & \multicolumn{3}{|c|}{ Confidence Intervals Bias Corrected } & \multirow{2}{*}{$\begin{array}{l}\text { Samples } \\
\text { ror (STERR) }\end{array}$} & \multirow{2}{*}{\multicolumn{2}{|c|}{$\begin{array}{l}\text { Export to } \\
\text { P Values }\end{array}$}} \\
\hline & & \multicolumn{2}{|c|}{ Original Sample $(0)$} & Sample Mean (M) & Standard Err & & & \\
\hline \multicolumn{2}{|c|}{ CAREER DEVELOPMENT $\rightarrow>$ PERFORMANCE } & \multicolumn{2}{|c|}{0.641} & 0.646 & & 0.069 & 9.232 & 0.000 \\
\hline \multicolumn{2}{|c|}{ COMPETENCE $->$ CAREER DEVELOPMENT } & \multicolumn{2}{|c|}{0.415} & 0.425 & & 0.071 & 5.819 & 0.000 \\
\hline \multicolumn{2}{|l|}{ COMPETENCE -> PERFORMANCE } & \multicolumn{2}{|c|}{0.305} & 0.301 & & 0.074 & 4.103 & 0.000 \\
\hline \multicolumn{2}{|l|}{ TRAINING -> CAREER DEVELOPMENT } & & 0.412 & 0.406 & & 0.074 & 5.583 & 0.000 \\
\hline \multicolumn{2}{|l|}{ TRAINING $->$ PERFORMANCE } & & 0.005 & 0.007 & & 0.065 & 0.073 & 0.942 \\
\hline
\end{tabular}

\subsection{Effect of training on lecturer career development}

Based on testing the first hypothesis, it was concluded that there was an influence of training on career development. Based on $(t=5.583>1,96)$. The results of this study are in line with or support studies that have been conducted by Al-Sharafi (2018), and the following research findings suggest that training, competency and career development variables can improve performance, including: Truit (2011), Karim (2019), Imran (2015), Mahmood (2018), Al- Sharafi (2018), and Boadu (2014). Based on the results of testing the hypothesis proposed above, it can be concluded that lecturers who often take part in seminars and get training programs will have more competence and good experience, so they will get opportunities in their career development.

\subsection{Influence of competence on the career development of lecturers}

The second hypothesis testing can be concluded that there is an influence of competence on career development. Based on $(\mathrm{t}=5.819>1.96)$. The results of the second hypothesis testing are consistent with research conducted by Truit (2011), Karim (2019), Imran (2015), Mahmood (2018), Al- Sharafi (2018), and Boadu (2014). Based on testing of the hypothesis proposed above, it can be concluded that lecturers who have good competence will be more likely to get career development at work.

\subsection{Effect of training on lecturer performance}

In testing the third hypothesis it is concluded that there is an effect of training on performance. Based on the statistical $t$ coefficient as follows $(t=0.073<1.96)$. These results contradict research conducted by Truit (2011), Asrizallis (2015), Wirotomo (2015), Ningsi (2015), Imran (2015), Candra (2016), Satriadi (2018), Watulo (2018), Mubarok (2015) 2018), Mahmood (2018), and Al Sharafi (2018), Al Karim (2019), in general the results of their research say that training can affect employee performance positively and significantly. Hypothesis testing can be concluded lecturers who are given training are not necessarily lecturers will perform well, it appears that there is an influence between training on career development but it is not significant.

\subsection{Effect of competence on lecturer performance}

The fourth hypothesis testing concluded that competence can affect performance. Based on the statistical $t$ coefficient $(t=4.103>1.96)$. The results of this study support studies that have been conducted by Hendra (2018), Rusvitawati (2019), Wirotomo (2015), Tafqihan (2014), Wahyuni (2019), Watulo (2018), Mubarok (2018), and Mahmood (2018), which in general concluded that the competency variable has an influence on employee performance with 
positive and significant values. In accordance with the results of the analysis of this hypothesis it can be concluded that lecturers who have competence in their field of work will perform better.

\subsection{Effect of career development on lecturer performance}

Hypothesis 5 test results conclude there is an influence between career development on performance. This is based on $(t=9.232>1,96)$. The conclusions of this study support and are in line with previous research conducted by Boadu (2014), Wirotomo (2015), Ningsi (2015), Siswadhi (2018), Marjanuardi (2019), Watulo (2018), Truit (2011), Al Karim (2019), Imran (2015), and Al Sharafi (2018) where their study generally concluded that career development variables had a positive effect on employee performance. So it can be concluded that lecturers who get attention in terms of career development, will perform better. And based on testing the 5th hypothesis it can also be concluded that the career development variable is an intervening variable for the training and competency variables in improving lecturer performance in Palembang, Indonesia, with an R2 coefficient of 0.537 or in other words a $53.7 \%$ training and competency variable through Career development variables in influencing performance.

\section{Conclusion And Suggestion}

Based on the results of the study it can be concluded that the training and competency variables can improve lecturer performance with or through career development first. If lecturers are given a clear career path, they will become actively studying and practicing to improve their competencies, this will encourage lecturers to perform better. Higher education institutions in Palembang, Indonesia are expected to provide clarity on the career development of lecturers through (mutation, selection, placement, education, and training), then consistently given training through (seminars) by bringing in experienced instructors, providing material and quality methods, as well as enhancing the competence of lecturers to increase their knowledge, understanding, abilities, skills, attitudes and interests in accordance with their fields of science.

\section{References}

Al Karim Rashed, 2019. Impact of Different Training and Development Programs on Employee Performance in Bangladesh Perspective. International Journal of Entrepreneurial Research 1(1); 8-14.

Al-Sharafi Hamed, Hassan Mat Mohd Ezani and Alam Syed Shah, 2018. The Effect of Training and Career Development on Employees Retention A Study on the Telecommunication Organizations in Yeman. The Journal of Social Science Reseach, Special Issue 2, pp: 240-430.

Asrizallis, 2015. Kontribusi Etos Kerja Islami dan Pelatihan terhadap Kinerja Guru Masdrasah Tsanawiyah Swasta (MTSS) Se-Kota Padang Panjang. Jurnal Al-Fikrah, Vol. III, No. 1, Januari-Juni. 
Boadu Francis, Fokuo Elizabeth Dwomo, Boakye Joseph Kofi, and Kwaning Collins Owusu, 2014. Training and Development: A Tool for Employee Performance in the District Assemblies in Ghana. International Journal of Educational and Research. Vol. 2 No. 5, May.

Dewi Angga Ariesta Ni Luh Putu, dan Utama Murdiartha I Wayan, 2016. Pengaruh Pengembangan Karir terhadap Kinerja Karyawan Melalui Mediasi Motivasi Kerja pada Karya Mas Art Gallery. E-Jurnal Manajemen Unud, Vol. 5 No. 9 (5494-5523)

Garaika, 2018. The Effects of Good University Governance and Organizational Culture Toward Lecturer Performance and its Influence on Private Universities Performance in the City of Lampung. Garaika, 2019. Self Efficacy, Selft Personality and Self Confidence on Entrepreneurial Intention: Study onYoung Enterprises. The Journal of Entrepreneurship Education, Vol. 22, pp. 1-12.

Garaika, D.F Fathurahman, Liestyana Yuli, dan Wahyuningsih Tri. 2019. Information Sharing, Supplier Performance, Supplier Trust on Supplier Sinergy. International Conference of Business, Economy, Entrepreneurship and Management, Vol. 1, pp.88

Hendra, Sugiati Tinik, Dewi Maya Sari, 2018. Peran Interaksi Kepuasan Kerja pada Pengaruh Budaya Organisasi dan Kompetensi terhadap Kinerja Pegawai (Studi pada Sekolah Tinggi Teologi Gereja Kalimantan Evangelis di Banjarmasin). Jurnal Wawasan Manajemen, Vol. 6 Nomor 1.

Imran Muhammad, and Tanveer Aiman, 2015. Impact of Training \& Development on Employees' Performance in Banks of Pakistan. European Journal of Training Development Studies, Vol. 3, No. 1 pp.22-44.

Mahmood Rahamah, Hee Ong Choon, YinOng Shze, Hamli Hanis Mohd Syafiq, 2018. The Mediating Effects of Employee Competency on the Relationship between Training Functions and Employee Performance. International Journal of Academic Research in Business and Social Sciences. 8(7), 664-676.

Margahana, and Garaika, 2019. The Influence of Credibility and Voluntariness Toward Technological Use Behavior: Entrepreneurial Potential Model Approach. International Journal of Entrepreneurship, Vol. 23, pp. 1-9

Marjanuardi Leti, dan Ratnasari Sri Langgeng, 2019. Pengaruh Disiplin Kerja, Loyalitas, dan Pengembangan Karir terhadap Kinerja Karyawan Yayasan Raudlatul Qur'an Batam. Jurnal Benefita 4(3) Oktober (560-569).

Mubarok Endang Saefuddin, and Putra Hidayatullah, 2018. The Influence of Training, Competence, and Motivation on Employees Performance of Workers Social Security Agency in Banten Province, Indonesia. Journal of Economics and Sustainable Development. Vol. 9 No. 4.

Ningsi Citra Ayu, Alhabsji Taher dan Utami Hamidah Nayati, 2015. Pengaruh Pelatihan dan Promosi terhadap Motivasi dan Kinerja Karyawan (Studi pada Karyawan PT. PLN (Persero) Area Kendari). Jurnal Administrasi Publik, Volume 5 No. 1 
Rusvitawati Devi, Sugiati Tinik, dan Dewi Maya Sari, 2019. Pengaruh Kompetensi terhadap Kinerja Karyawan Rumah Sakit Sari Mulia Banjarmasin. Jurnal Wawasan Manajemen, Vol. 7 Nomor 1.

Satriadi, Agusven Tubel, Kusumah Surya, dan Sandra Evita, 2018. Pengaruh Motivasi dan Pelatihan terhadap Kinerja Karyawan. Jurnal Program Studi Pendidikan Ekonomi STKIP PGRI Sumatera Barat Vol. 7, No. 1 (7-18)

Siswadhi Ferry, dan Sudirman, 2018. Analisis Dampak Pengembangan Karir dan Motivasi terhadap Kinerja Pegawai Dinas Koperasi dan UMKM Kabupaten Kerinci. Jurnal Benefita 3 (1) Februari.

Suryawan Yudi I Gede Made, dan Suwandana I Gusti Made, 2019. Peran Motivasi Kerja dalam Memediasi Pengaruh Pengembangan Karir terhadap Kinerja Karyawan. E-Jurnal Manajemen, Vol. 8 No. 10 (6002-6021)

Tafqihan Zuhdy, dan Suryanto, 2014. Pengaruh Kompetensi Guru terhadap Komitmen Profesional dan Dampaknya pada Kinerja Serta Kepuasan Kerja Guru Matematika SMP dan MTS. Jurnal Riset Pendidikan Matematika, Volume 1 -Nomor 2, November.

Triut Debra L, 2011. The Effect of Training and Development on Employee Attitude as it Relates to Training and Work Proficiency. Journal SAGE Open 1-13.

Wahyuni Hani, 2019. Pengaruh Kompetensi, Motivasi Kerja dan Kepuasan Kerja terhadap Kinerja Dosen, Jurnal Manajemen dan Kewirausahaan, Vol. 7 No. 2: 154-162

Watulo Angelita Gabriel, Sendow Greis M, dan Saerang Regina, 2018. Pengaruh Pelatihan, Pengembangan Karir, dan Kompetensi terhadap Kinerja Karyawan pada Bank Sulutgo Pusat di Manado. Jurnal EMBA, Vol. 6 No. 4, September, hal. 2308-2317.

Wirotomo Dono dan Pasaribu Popy Novita, 2015. Pengaruh Kompetensi, Pengembangan Karir, Pendidikan dan Pelatihan (Diklat) terhadap Kinerja Pegawai Direktorat Jenderal Perimbangan Keuangan. Jurnal MIX, Volume V, No. 3, Oktober. 